\title{
ИЗМЕНЕНИЕ ЭЛЕКТРОПРОВОДНОСТИ ЛИТОСФЕРЫ В РАЙОНЕ ОЧАГА СИЛЬНЕЙШЕГО ОЛЮТОРСКОГО ЗЕМЛЕТРЯСЕНИЯ В КОРЯКСКОМ НАГОРЬЕ
}

\author{
(C) 2016 г. Ю. Ф. Мороз ${ }^{1,2}$, Т. А. Мороз ${ }^{1}$, В. А. Логинов ${ }^{1,5}$, \\ А. Г. Нурмухамедов ${ }^{3}$, Д. А. Алексеев ${ }^{4}$ \\ ${ }^{1}$ Институт вулканологии и сейсмологии ДВО РАН, г. Петропавловск-Камчатский \\ E-mail: morozyf@kscnet.ru \\ ${ }^{2}$ Геологический институт СО РАН, г. Улан-Удэ \\ ${ }^{3} О А О$ “Камчатгеология”, г. Петропавловск-Камчатский \\ ${ }^{4} \mathrm{OAO}$ “Северо-Запад“, г. Москва \\ ${ }^{5}$ Камчатский государственный университет им. Витуса Беринга, г. Петропавловск-Камчатский \\ Поступила в редакцию 27.12.2013 г.
}

\begin{abstract}
Рассмотрены результаты магнитотеллурического зондирования до и после землетрясения. В основу интерпретации положены кривые МТЗ по направлениям, отвечающим простиранию и вкрест про-

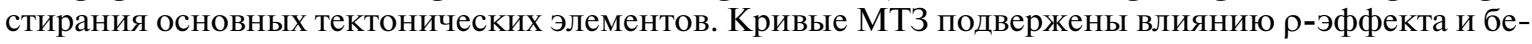
регового эффекта. Оценка влияния берегового эффекта выполнена с помощью пробной трехмерной модели. Установлено, что на периодах до 1000 с влияние берегового эффекта невелико, и им можно пренебречь. Детально исследован эффект расхождения продольной и поперечной кривых МТ3, отражающий наличие глубинных разломов. Инверсия кривых МТЗ выполнена с помощью программы численного двумерного моделирования REBOCC. В ней использованы процедуры погашения эффекта $\rho$ и совместной инверсии продольной и поперечной кривых МТЗ. Полученные геоэлектрические разрезы дают представление о структуре электропроводности литосферы до и после землетрясения. Изменения электропроводности в большей мере проявились в зоне глубинных разломов. Они связываются с изменением пористости и степени насыщенности пород высокоминерализованными растворами.
\end{abstract}

Ключевые слова: электропроводность, литосфера, магнитотеллурическое зондирование, разлом, землетрясение, гипоцентр, афтершоки.

DOI: $10.7868 / \mathrm{S} 0002333716010063$

В Корякском нагорье в 2006 году произошло сильнейшее Олюторское землетрясение (20.04.2006; $\left.M_{w}=7.6\right)$. Оно предварялось сильным Хаилинским землетрясением в 1991 году (08.03.1991; $\left.M_{w}=6.6\right)$. Эпицентры землетрясений по разным оценкам находятся на расстояниях от 12 до 25 км [Ландер и др., 1994; Ландер и др., 2010]. Олюторское землетрясение превосходило по силе все наблюдавшиеся ранее сейсмические события. После главного толчка в течение 12 часов произошло еще 9 сильных землетрясений с $\mathrm{K}_{\mathrm{s}} \geq 11.6$ и более 200 слабых. По указанным землетрясениям определена очаговая область, показанная на рис. 1 [Ландер и др., 2010]. Она изучена методами магнитотеллурического (МТ3) и магнитовариационного зондирований (МВ3). Важно отметить, что по профилю I-I наблюдения МТЗ выполне- ны в 2001 году до землетрясения и повторены в 2008 году после него. Магнитотеллурические исследования выполнены "Восточным геофизическим трестом", предприятиями "Камчатгеология”, “Геон” и “Северо-Запад”. Полученные данные дают возможность оценить, в какой мере изменилась электропроводность геологической среды в связи с Олюторским землетрясением. Этому вопросу и посвящена настоящая статья.

\section{КРАТКАЯ ГЕОЛОГО-ГЕОФИЗИЧЕСКАЯ ХАРАКТЕРИСТИКА РАЙОНА}

Геологическое строение региона в полной мере рассмотрено в работе [Геология..., 1970а; б]. В последующие годы по мере накопления геологогеофизических материалов появилось большое 


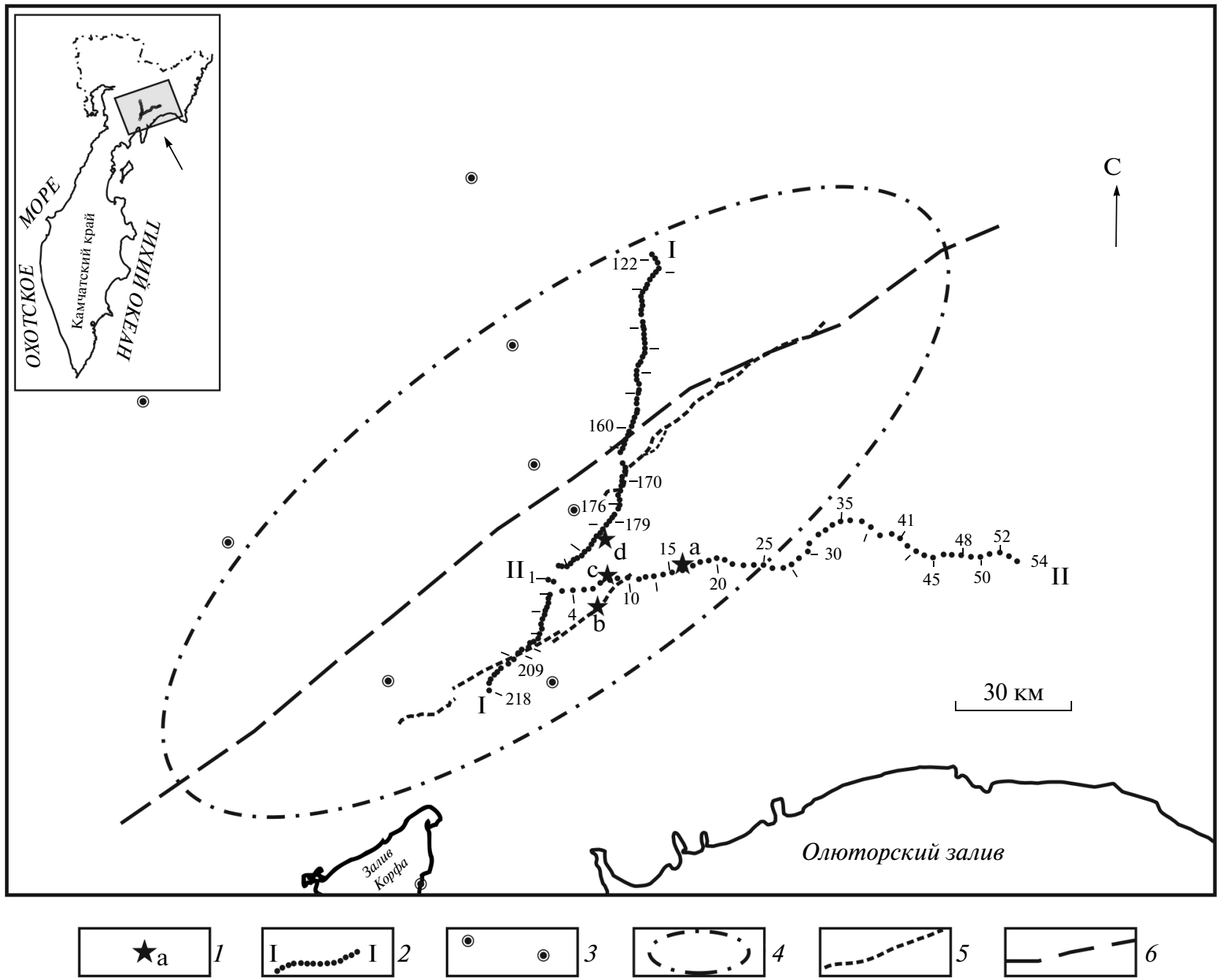

Рис. 1. Схема расположения профилей электромагнитного зондирования: 1 - эпицентры Олюторского землетрясения по данным: a - КФГС РАН [Каталог землетрясений Камчатки и Командорских островов 1962-2006]; b - CMT [Harvard CMT catalog]; c - USGS [National Earthquake Information Centre]; d - СБ ГС РАН [Сейсмологический бюллетень за 2006 год]; 2 - профили МТЗ - каждая точка соответствует пункту наблюдения, номерами обозначены только некоторые пункты МТЗ; 3 - маршрутные МТЗ [Мороз, 1987]; 4 - контур очага землетрясения [Ландер и др., 2010]; 5 - сейсмотектонические разрывы [Пинегина, 2007; Рогожин и др., 2007]; 6 - глубинный разлом в области сочленения Корякской и Олюторской складчатых зон [Мороз, 1987]. На профиле МТЗ цифрами обозначены лишь номера МТ3, которые необходимы для пояснения в статье содержания графиков и разрезов. На врезке показан район исследований с профилями МТЗ.

число опубликованных геолого-структурных карт и схем, геологических, геолого-геофизических разрезов, характеризующих предполагаемое глубинное строение региона. Согласно геодинамическим представлениям [Чехович и др., 2009], область северной Камчатки и ее Корякского нагорья в позднем мелу и кайнозое рассматривается как аккреционно-коллизионная система. Она отражает присоединение к краю Азиатского континента различных крупных литосферных ансамблей (терригенов). Северную часть площади занимает Центрально-Корякский терриген, являющийся частью Камчатского-Корякского микроконтинента [Некрасов, 2003]. По данным сейсмологии вы- сказана гипотеза о существовании современной малой литосферной плиты - Беренгии [Ландер и др., 1994]. В рамках этой гипотезы показано, что сейсмическая активность Корякской окраины может быть связана со становлением западной границы этой плиты [Ландер и др., 1994]. Наряду с этими представлениями существуют и многие другие [Fujita et al., 2007; Scholl, 1999; Апрелков, Попруженко, 2009]. Они дополняют представления о геодинамике региона, хотя и во многом противоречивы. Это связано со сложным геологическим строением исследуемой территории и недостаточной изученностью ее глубинного строения. 
Очаг Олюторского землетрясения приурочен к области сочленения Корякской и Олюторской складчатых зон (рис. 1). Корякская зона сложена меловыми, палеогеновыми и неогеновыми образованиями. Здесь выделяются синклинории, антиклинории и прогибы. В структурах широко развиты разломы глубинного заложения. Они расчленяют складчатые структуры на ряд узких протяженных блоков северо-восточного простирания [Геология..., 1970б].

Олюторская зона характеризуется более сложным геологическим строением. В ее основании залегает меловой складчатый комплекс, который выступает в поднятии Олюторского п-ова и в ядре Пылгинского антиклинория. На складчатом основании несогласно залегают вулканогенно-кремнистые и терригенные породы палеогена, которые перекрыты комплексом пород, представленных морскими молассовыми формациями среднего и позднего миоцена. Верхний структурный ярус сложен грубообломочными морскими, континентальными и вулканогенными породами верхнего миоцена и четвертичного периода. Следует отметить, что складчатые структуры Олюторской зоны представляют собой сопряженные антиклинории и синклинории, вытянутые в северо-восточном направлении на расстоянии 150-200 км и более. Ширина структур составляет около 30-40 км. Они более сжаты на юго-западе и несколько расширены на северо-востоке. Крылья антиклинориев и синклинориев часто ограничены разрывными нарушениями. Отмечаются поперечные дизъюнктивы, которыми они расчленяются на ряд блоков [Геология..., 1970б].

Представление о глубинном строении района дают данные комплексного анализа МТЗ, магнитометрии, гравиметрии и других геолого-геофизических данных, представленных на рис. 2 [Мороз, 1987]. Корякская и Олюторская складчатые области разграничены глубинным разломом, который является продолжением Камчатского глубинного разлома протягивающегося на расстояние свыше 1000 км. Он выражен в магнитном поле линейными зонами интенсивных положительных или отрицательных аномалий. В гравитационном поле разлом характеризуется зонами высоких градиентов или узкими полосами аномалий и аномальными вытянутыми зонами. Наряду с разломами северо-восточного простирания выделяется ряд поперечных северо-западных разломов. Они отличаются меньшими размерами и слабее выражены в геофизических полях. Широко развитая сеть разломов определяет складчато-блоковое строение региона и играет большую роль в его сейсмичности и металлогении.

Магнитное и гравитационное поля северо-западной части очаговой области, входящей в состав Корякской складчатой зоны, характеризуются от- носительно спокойным поведением аномалий. Юго-восточная часть очаговой области, входящей в состав Олюторской складчатой области, отличается возмущенным поведением магнитного и гравитационного полей. Аномалии, по-видимому, связаны с глубинным разломом, по которому магматические породы проникли в верхние толщи земной коры.

По данным МТЗ, ВЭЗ верхняя часть разреза, сложенная четвертичными и современными образованиями мощностью до 1000 м, имеет удельное электрическое сопротивление в первые сотни Ом м и более. Ниже залегает кайнозойская толща мощностью от первых сотен метров до первых километров со средним продольным электрическим сопротивлением от первых сотен до первых десятков Ом м. Осадочновулканогенная кайнозойская толща подстилается верхнемеловым комплексом пород с удельным электрическим сопротивлением 500-1000 Ом м и более. На структурной схеме по поверхности верхнемелового комплекса, представленной на рис. 2, эпицентры Олюторского землетрясения приурочены к Вывенскому прогибу, в основании которого находится глубинный разлом. Прогиб имеет продолжение в сторону Берингово моря. Он в районе очаговой области выполнен толщей низкоомных кайнозойских отложений мощностью до 3 км со средним продольным электрическим сопротивлением единицы-первые десятки Ом м. Повышенная электропроводность нижней части кайнозойской толщи связывается с повышенной пористостью пород и насыщенностью их минерализованными водами.

По данным МТЗ литосфера содержит слой повышенной электропроводности на глубинах в первые десятки километров с удельным электрическим сопротивлением в первые десятки Ом м. В районе крупных глубинных разломов, проникающих в земную кору, проводящие зоны проявляются на глубинах 8-10 км [Мороз, 1987].

В 2004-2005 гг. по данным методов обменных волн землетрясений (МОВ3) и магнитотеллурического зондирования получены сейсмические и геоэлектрические характеристики литосферы по профилю Верхнее Пенжино-Корф [Белявский и др., 2008]. Мощность и электропроводность осадочно-вулканогенного чехла Вывенской впадины согласуются с оценками, приводимыми в работе [Мороз, 1987]. В земной коре также выделяется проводящий слой, связываемый с наличием флюидов. Наряду с этим в земной коре и в верхних частях мантии показаны зоны повышенной электропроводности. Некоторые из них являются вертикальными. О достоверности выделенных зон судить трудно, так как они не подтверждены другими геофизическими данными. По сейсмическим данным мощность земной коры в Вывенской впадине составляет 40 км. Грани- 


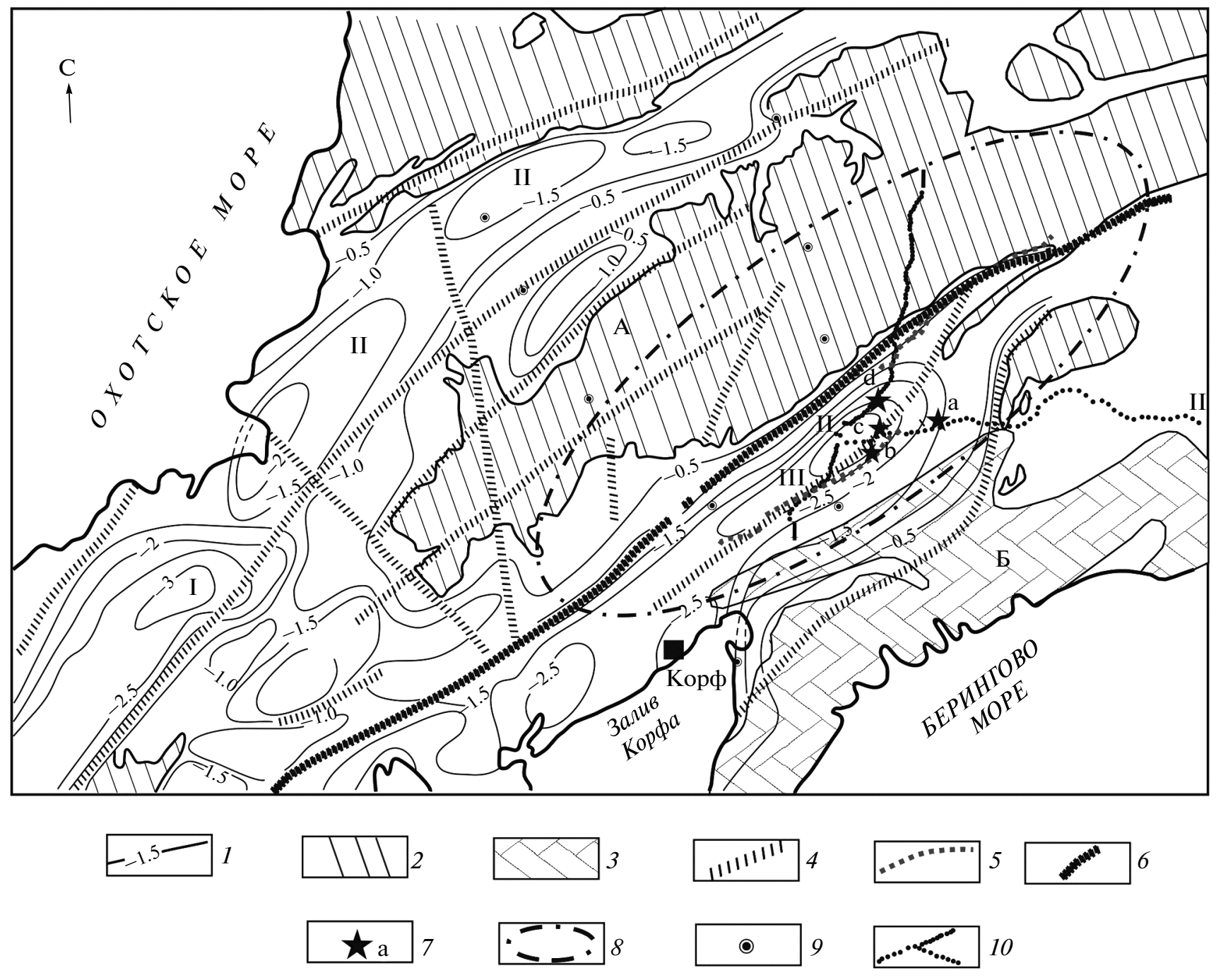

Рис. 2. Структурная схема по поверхности верхнемелового комплекса [Мороз, 1987] с дополнениями: 1 - изогипсы, км; 2 и 3 - выходы пород верхнемелового и палеогенового комплексов пород; 4 - разломы; 5 - сейсмотектонические разрывы [Пинегина, 2007; Рогожин и др., 2007]; 6 - глубинный разлом в области сочленения Олюторской и Корякской складчатых зон; 7- эпицентры землетрясений (см. рис. 1); 8-контур очага Олюторского землетрясения [Ландер и др., 2010]; 9 - маршрутные МТЗ [Мороз, 1987]; 10 - профили МТЗ. А и Б - Корякская и Олюторская складчатые зоны. I, II и III - Пусторецкая впадина, Парапольский и Вывенский прогибы.

цы областей изменения волновой картины обменных волн часто наклонены в западном направлении. На разрезах выделено большое количество разрывных нарушений, проникающих на глубины 40-50 км. При этом расстояние между ними составляет иногда 10 км и менее, что находится за пределами разрешающей способности метода. Несмотря на это, полученные результаты в значительной мере уточняют и дополняют существующие представления о глубинном строении региона.

Сейсмичность, связанная с Олюторским землетрясением подробно рассмотрена в работе [Ландер и др., 2010]. Гипоцентр землетрясения определен по данным: КФ ГС РАН (http://emsd.iks.ru), СБ ГС РАН
(ftp://ftp.gsras.ru/pub/Teleseismic_Catalog), CMT (http://www.globalcmt.org/CMTsearch.html), USGS (http://neic.usgs.gov/neis/epic/epic.html). Глубина гипоцентра по этим источникам составляет 1-20 км. Для афтершоков землетрясения 2-17 мая получены более точные оценки глубин по данным дополнительной сети станций, установленной в пределах эпицентральной зоны. Глубины афтершоков не превышают 27 км. Точность определения глубины для большинства землетрясений выше 5 км. По эпицентрам всех зарегистрированных землетрясений выделена очаговая область, которая изображенав виде эллипса размерами $205 \times 75$ км и простиранием большой оси 55 градусов. Максимальная плотность афтершоков отмечается в районе сейсмотектонических нарушений, выявленных 
вдоль юго-восточного борта долины р. Вывенки [Пинегина, 2007; Рогожин и др., 2007].

\section{МЕТОДИКА РАБОТ}

Маршрутные исследования методом МТЗ проведены с помощью аппаратуры ЦЭС-2. Шаг между пунктами наблюдений составляет первые десятки километров. Вариации магнитотеллурического поля зарегистрированы в диапазоне 1-3000 с.

В 2001 году до землетрясения по профилю I-I выполнены МТ3 с шагом 2-5 км. После землетрясения в 2008 году проведены повторные наблюдения МТ3 на тех же пунктах, а также выполнены МТ3 на профиле II-II с таким же шагом 25 км. На ряду с МТЗ в 2008 году получены МВ3. Регистрация магнитотеллурического поля осуществлялась в диапазоне периодов $0.0025-1000$ с с помощью станций MTU-5А производства канадской фирмы "Phoenix Geophysics Ltd". Для регистрации электротеллурического поля использована пятиэлектродная крестообразная измерительная установка. В качестве заземлений применялись слабополяризующиеся электроды. Длина электрических линий 80 м. Азимут линий в 2001 году был 0 и 90 градусов, а в 2008 году 30 и 120 градусов. Горизонтальные магнитные датчики укладывались в ямы глубиной около 30 см и сверху присыпались землей. Вертикальные датчики зарывались в землю, а в условиях каменистой почвы устанавливались на треноге. Измерения МТ-поля осуществлялись несколькими станциями MTU-5, разнесенными на необходимое расстояние. Для подавления промышленных помех использована методика синхронных измерений с использованием удаленной базовой станции. На участках профиля с низким уровнем промышленных помех в качестве базовой станции использовалась станция на одной из точек профиля. Обработка магнитотеллурических данных выполнена предприятиями “Геон” и “Северо-Запад”. В результате обработки получены тензоры импеданса и магнитного типпера в диапазоне периодов от 0.0025 до 1000 с и более. Точность определения модулей магнитотеллурических параметров составляет первые проценты, фаз импеданса - первые градусы.

\section{ИНТЕРПРЕТАЦИЯ \\ МАГНИТОТЕЛЛУРИЧЕСКИХ ЗОНДИРОВАНИЙ}

Тензор импеданса дает возможность оценить характер и степень геоэлектрической неоднородности среды. Анализ выполнен с помощью полярных диаграмм импеданса [Бердичевский, Дмитриев, 2009], параметра неоднородности [Bahr, 1988] и параметра асимметрии [Swift, 1967]. Параметр неоднородности имеет значения первые десятые доли на коротких периодах. На длин- ных периодах указанный параметр возрастает, что связано с влиянием крупных структур. Параметр асимметрии свидетельствует, что на длинных периодах геоэлектрические неоднородности в первом приближении можно аппроксимировать в качестве двумерных, что связано с вытянутостью структур в северо-восточном направлении. В основу интерпретации приняты кривые, полученные в главных направлениях. Они в большинстве случаев ориентированы по простиранию и вкрест простирания основных структурных зон. В дальнейшем эти кривые будем называть продольными и поперечными.

Анализ показывает, что кривые МТЗ подвержены влиянию эффекта $\rho$. Это хорошо видно на рис. 3 , где в качестве примера приведены характерные семейства близко расположенных кривых MT3 в районах Вывенского прогиба (профиль I-I, МТ3 № 163-170) и Хахинанского антиклинория (профиль II-II, МТ3 № 19-26). Кривые кажущегося электрического сопротивления в семействах расходятся по уровню сопротивлений почти на порядок, а фазовые кривые являются близкими в низкочастотной области.

Кривые различаются по форме, что связано с геоэлектрической неоднородностью среды. В прогибе продольные и поперечные кривые на периодах 0.7-2 с имеют минимум, отражающий наличие осадочно-вулканогенного чехла пониженного электрического сопротивления. В большей мере минимумы выражены во впадинах прогиба, выполненных, преимущественно, терригенными осадочными отложениями. Максимумы в средней части кривых МТЗ обусловлены слоем земной коры повышенного электрического сопротивления. Большинство кривых в правой части представлены нисходящей ветвью или минимумом, которые могут быть связаны как с глубинным проводящим слоем, так и с индукционным влиянием электрических токов, концентрирующихся в Олюторском заливе Берингового моря и в Пенжинской губе Охотского моря.

Поэтому с помощью численного трехмерного моделирования магнитотеллурического поля изучен береговой эффект в пробной модели, схема которой изображена на рис. 4. В ней мощность и удельное электрическое сопротивление осадочно-вулканогенного чехла на суше приняты постоянными. Это дает возможность оценить влияние берегового эффекта, независимо от влияния геоэлектрических неоднородностей осадочно-вулканогенного чехла. Геоэлектрические параметры верхнего слоя на суше приняты средними для исследуемой площади из работы [Мороз, 1987]. Мощность осадочно-вулканогенного чехла составляет 3 км, а удельное электрическое сопротивление 20 Ом м. Удельное электрическое сопротивление морской воды принято 0.25 Ом м. Глу- 
(a)
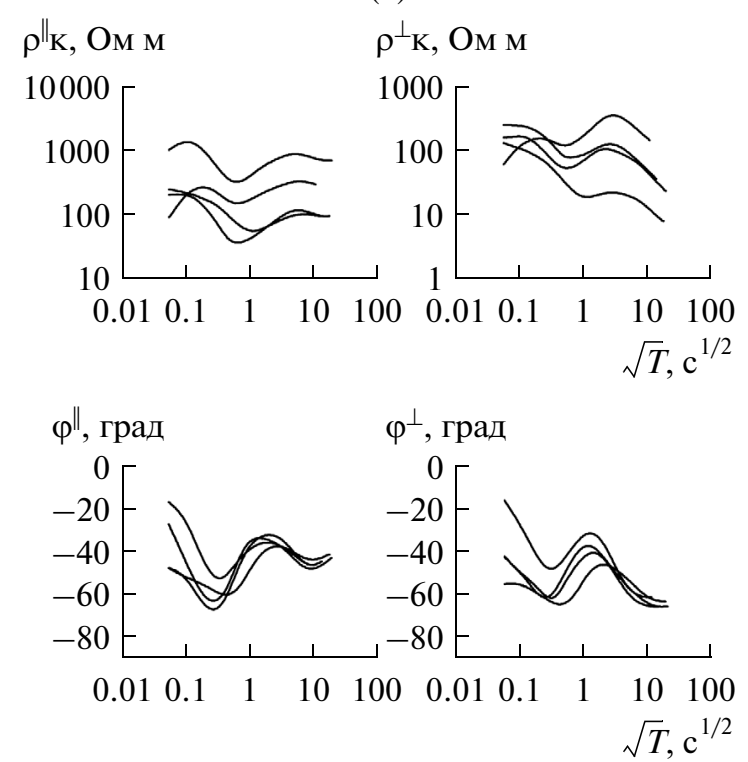

(б)
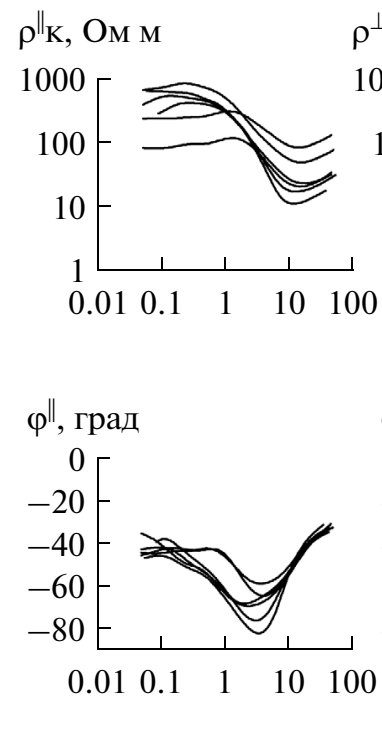

$\rho^{\perp} \mathrm{K}$, Ом м

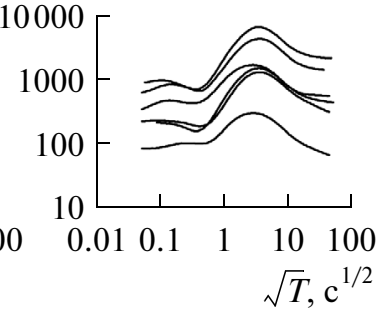

$\varphi^{\perp}$, град

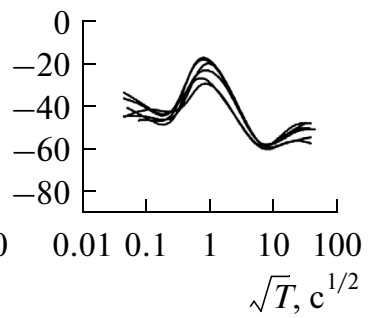

Рис. 3. Характерные кривые МТЗ: (а) и (б) - семейства продольных и поперечных кривых МТЗ на профилях I-I (МТ3 № 163-170) и II- II (МT3 № 19-26).

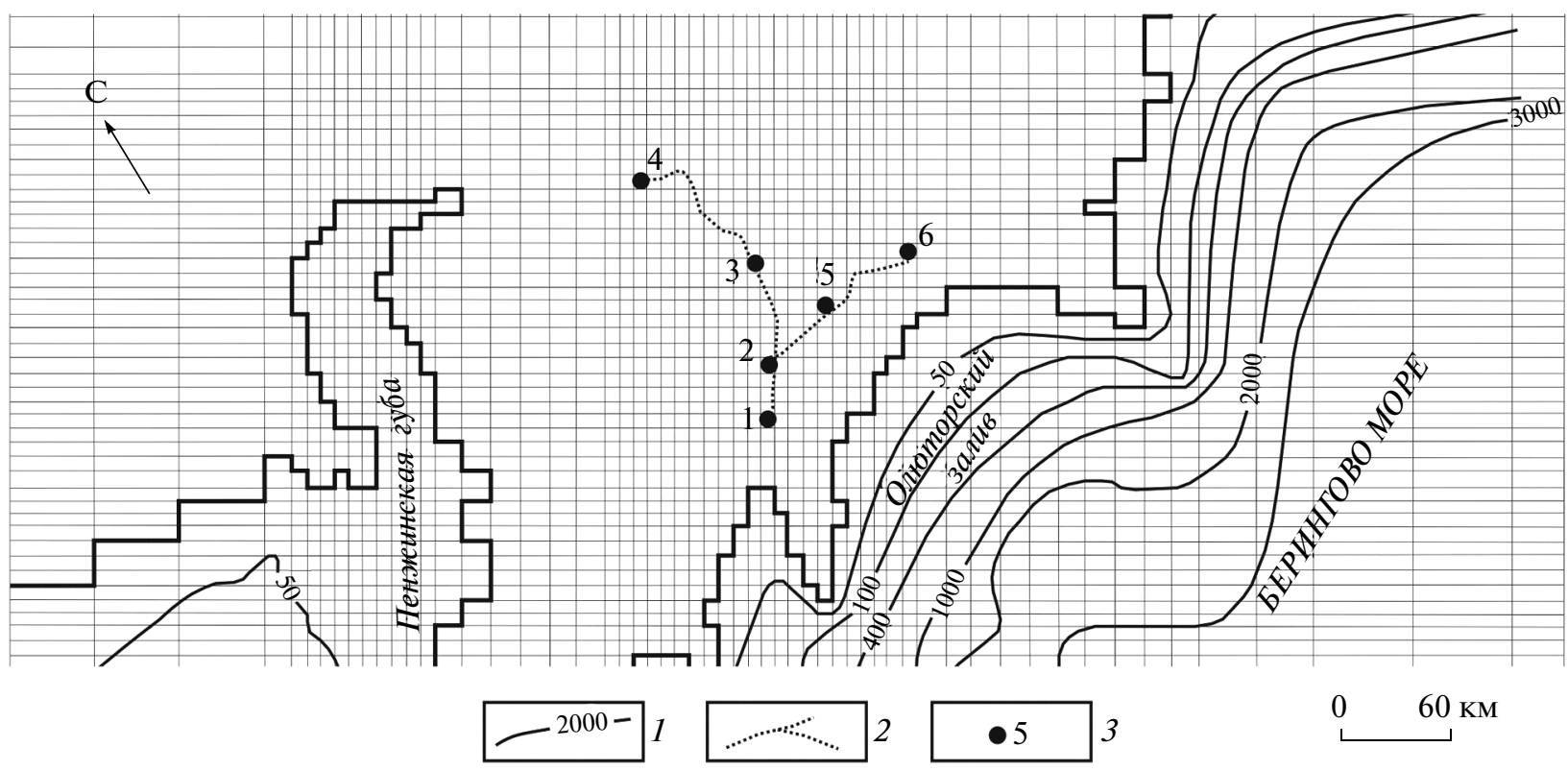

Рис. 4. Схема сеточной трехмерной пробной модели для изучения берегового эффекта:

1 - изобаты в м. Изобаты отвечают проводимости морской толщи воды в См в следующем виде: 50 м - 200 См, 100 м 400 См, 1000 м - 4000 См, 2000 м - 8000 См; 2 - профили МТ3; 3 - пункты, в которых получены модельные кривые МТЗ (рис. 5 и 6).

бинные геоэлектрические разрезы континента и дна океана приняты из работы [Ваньян, 1997] для теплового потока изучаемой территории в 60 мВт/м² и возраста дна омывающих морей и оке- ана в 40 млн лет [Смирнов, 1980; Геология..., 1970a].

Глубинные геоэлектрические разрезы континента и дна океана приведены в таблице. 
В результате моделирования по программе Макки [Mackie et al., 1994] получены продольная, поперечная и локально-нормальная кривые МТ3 в пунктах, показанных на рис. 4. На рис. 5 видно, что амплитудные модельные продольные и поперечные кривые практически совпадают с локальнонормальной кривой до периода 100 с. С увеличением периода отмечается отклонение амплитудной поперечной кривых от локально-нормальной кривой. Это отклонение на периодах 400-900 с составляет первые десятки процентов. Расхождение амплитудной продольной и локально-нормальной кривых до периода 1600 с не превышает 10-20\%. В низкочастотной области на периодах более 1600 с начинается действие регионального трехмерного берегового эффекта. Он выражен отклонением продольной кривой от локально-нормальной кривой в низкочастотной области в сторону высоких сопротивлений.

Рассмотрим кривые МТЗ в модели, содержащей литосферный проводящий слой. Он был выявлен по данным предшествующих магнитотеллурических исследований. Проводящий слой расположен на глубинах 20-30 км с удельным электрическим сопротивлением в первые десятки Ом м. В модель со стандартным распределением глубинной электропроводности введен литосферный проводящий слой, верхняя граница которого располагается на глубине 25 км. Мощность слоя 25 км, удельное электрическое сопротивление 50 Ом м. Результаты моделирования приведены на рис. 6.

Продольная и локально-нормальная кривые кажущегося сопротивления являются близкими на периодах до 2500 с. Поперечная амплитудная кривая согласуется с локально-нормальной кривой на периодах до 400 с. В низкочастотном диапазоне поперечная кривая отклоняется от локальнонормальной кривой. Однако это отклонение не превышает 10-15\% на периоде 900 с на пунктах 1 и 2, приближенных к морскому берегу. Характерно, что амплитудная продольная кривая на периодах более 2500 с также как и в первой модели отклоняется от локально-нормальной кривой в сторону высоких сопротивлений из-за влияния регионального трехмерного берегового эффекта. Таким образом, можно полагать, что продольные и поперечные кривые МТЗ до периода 900 с слабо затронуты береговым эффектом и характеризуют распределение электропроводности геологической среды.

Анализ магнитотеллурических данных и результаты изучения пробных моделей свидетельствуют, что продольные кривые МТЗ обладают повышенной разрешающей способностью к наличию проводящих слоев в земной коре и верхней мантии, а поперечные кривые МТЗ содержат информацию о высокоомных экранах [Бердичевский, Дмитриев, 2009]. Глубинные разломы выражены расхождением низкочастотных ветвей про-
Таблица

\begin{tabular}{c|l|c|l}
\hline \multicolumn{2}{c|}{ Континент } & \multicolumn{2}{c}{ Океан } \\
\hline \multicolumn{1}{c}{$H, \mathrm{м}$} & \multicolumn{1}{c}{$\rho$, Ом м } & $H, \mathrm{м}$ & $\rho$, Ом м \\
\hline$H_{1}=65000$ & $\rho_{1}=1000$ & $H_{1}=20000$ & $\rho_{1}=1000$ \\
\hline$H_{2}=40000$ & $\rho_{2}=500$ & $H_{2}=20000$ & $\rho_{2}=500$ \\
\hline$H_{3}=40000$ & $\rho_{3}=100$ & $H_{3}=25000$ & $\rho_{3}=100$ \\
\hline$H_{4}=100000$ & $\rho_{4}=50$ & $H_{4}=40000$ & $\rho_{4}=50$ \\
\hline$H_{5}=200000$ & $\rho_{5}=20$ & $H_{5}=340000$ & $\rho_{5}=20$ \\
\hline$H_{6}=300000$ & $\rho_{6}=10$ & $H_{6}=300000$ & $\rho_{6}=10$ \\
\hline
\end{tabular}

дольной и поперечной кривых МТЗ. Такой эффект назван эффектом “расхождения" [Бердичевский, Дмитриев, 2009]. На рис. 7 приведены продольные и поперечные кривые МТЗ в пп. 209, 176. Расхождение ориентированных кривых в низкочастотной области достигает почти порядка, что указывает на существование разломов в районе указанных пунктов. Для получения геоэлектрических разрезов, которые могут содержать проводящие слои, глубинные разломы и другие геоэлектрические неоднородности, целесообразно использовать совместную инверсию продольной и поперечной кривых МТЗ. При этом необходимо подавление влияния локальных гальванических эффектов.

\section{ЭЛЕКТРОПРОВОДНОСТЬ ГЕОЛОГИЧЕСКОЙ СРЕДЫ ОЧАГОВОЙ ОБЛАСТИ ОЛЮТОРСКОГО ЗЕМЛЕТРЯСЕНИЯ}

Об изменении электропроводности среды на качественном уровне можно судить из сравнения продольных кривых МТЗ до и после землетрясения, которые в качестве примера приведены на рис. 8. На фазовых кривых импеданса влияние глубинных разломов проявляется на более ранних периодах в низкочастотной области, чем на амплитудных кривых. Расхождение фаз до и после землетрясения на периодах 50-100 с составляет от 4 до 18 градусов, что в несколько раз превышает точность их определения. Характерно, что за пределами зон разломов, расхождение фазовых кривых является незначительным и не превышает ошибок их определения. Более полное представление дает рис. 9, где приведен псевдоразрез разности фаз продольного импеданса до и после землетрясения по профилю. Изменения фаз от -4 до -16 градусов выражены, как будет показано ниже на границах аномальных зон, приуроченных к разломам. Приведенные рисунки свидетельствуют, что в исходных данных содержится информация об изменении глубинной 

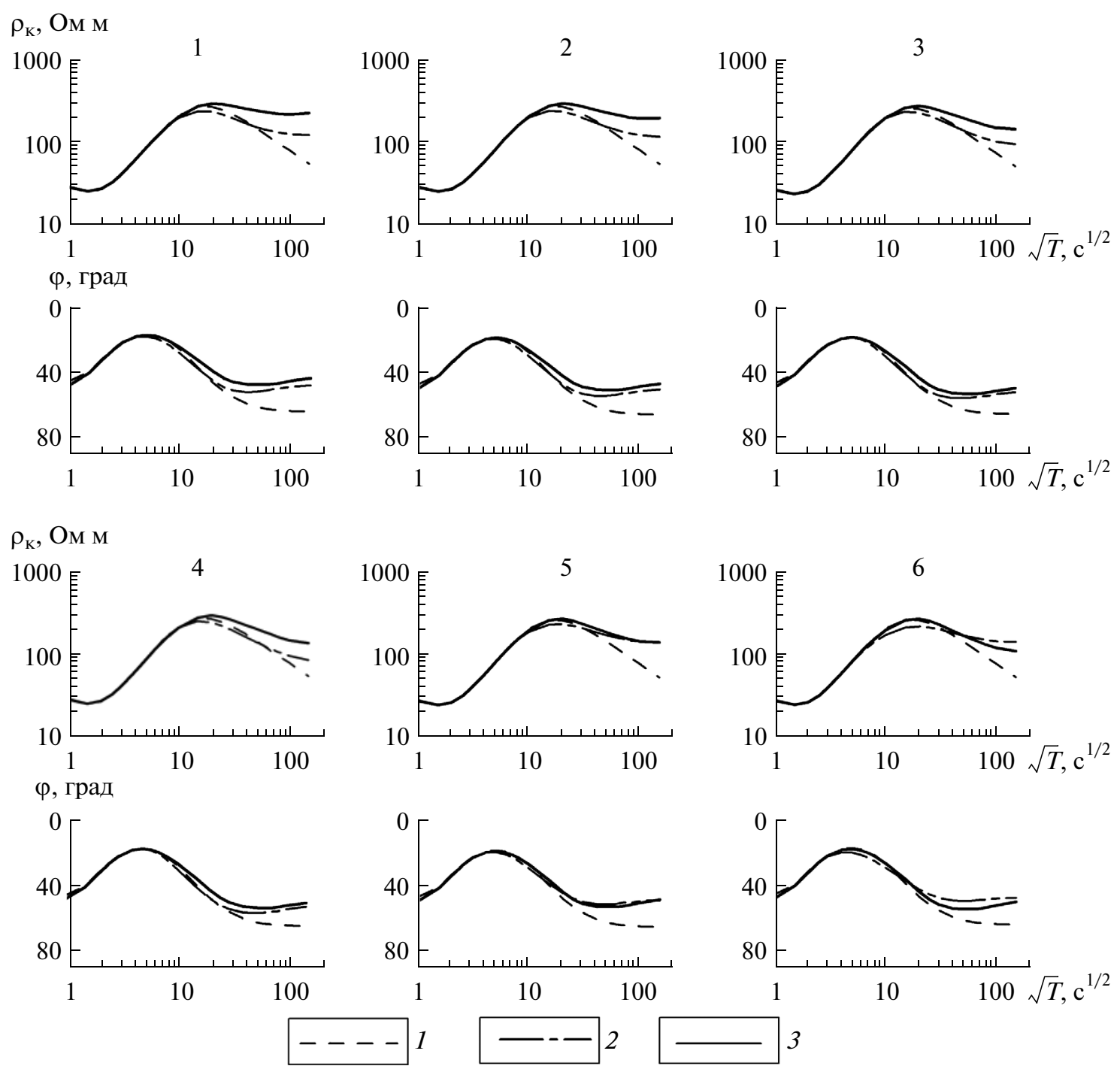

Рис. 5. Кривые МТЗ в пробной модели со стандартным распределением глубинной электропроводности: 1, 2 и 3 - локально-нормальная, продольная и поперечная кривые МТЗ. Цифрами над кривыми обозначены номера пунктов, показанных на рис. 4.

электропроводности геологической среды в связи с землетрясением.

Обратная задача решена с помощью программы REBOCC [Siripunvaraporn, Egbert, 2000]. В качестве исходной информации использованы тензоры импеданса в диапазоне периодов 0.00251000 с, полученные по профилю I-I (пп. 218-122) до и после землетрясения. Инверсия продольных кривых осуществлялась одновременно с поперечными кривыми. Это дало возможность выявить характерные особенности геоэлектрического разреза и получить информацию о субвертикальных проводящих зонах. При решении обратных задач по профилю I-I до и после землетрясения рассмотрены различные альтернативные модели. В ряде случаев менялась электропроводность, но была неизменна конфигурация аномальной зо- ны. Выполнено большое количество расчетов. Однако лучшей сходимости экспериментальных и модельных кривых удалось получить для геоэлектрических разрезов, приведенных ниже. Для них на рис. 10 и рис. 11 приведено сопоставление практических и модельных кривых в пунктах, где выявлены глубинные аномалии электропроводности. Согласие кривых очевидно, что свидетельствует о достоверности выделенных глубинных проводящих зон.

Обратимся к геоэлектрическому разрезу до землетрясения по данным инверсии кривых МТЗ (рис. 12). В верхних частях разреза (МТЗ № 218170) до глубин в первые километры выделяются аномалии повышенной электропроводности с удельным электрическим сопротивлением в первые единицы-десятки Ом м. Они связываются с 

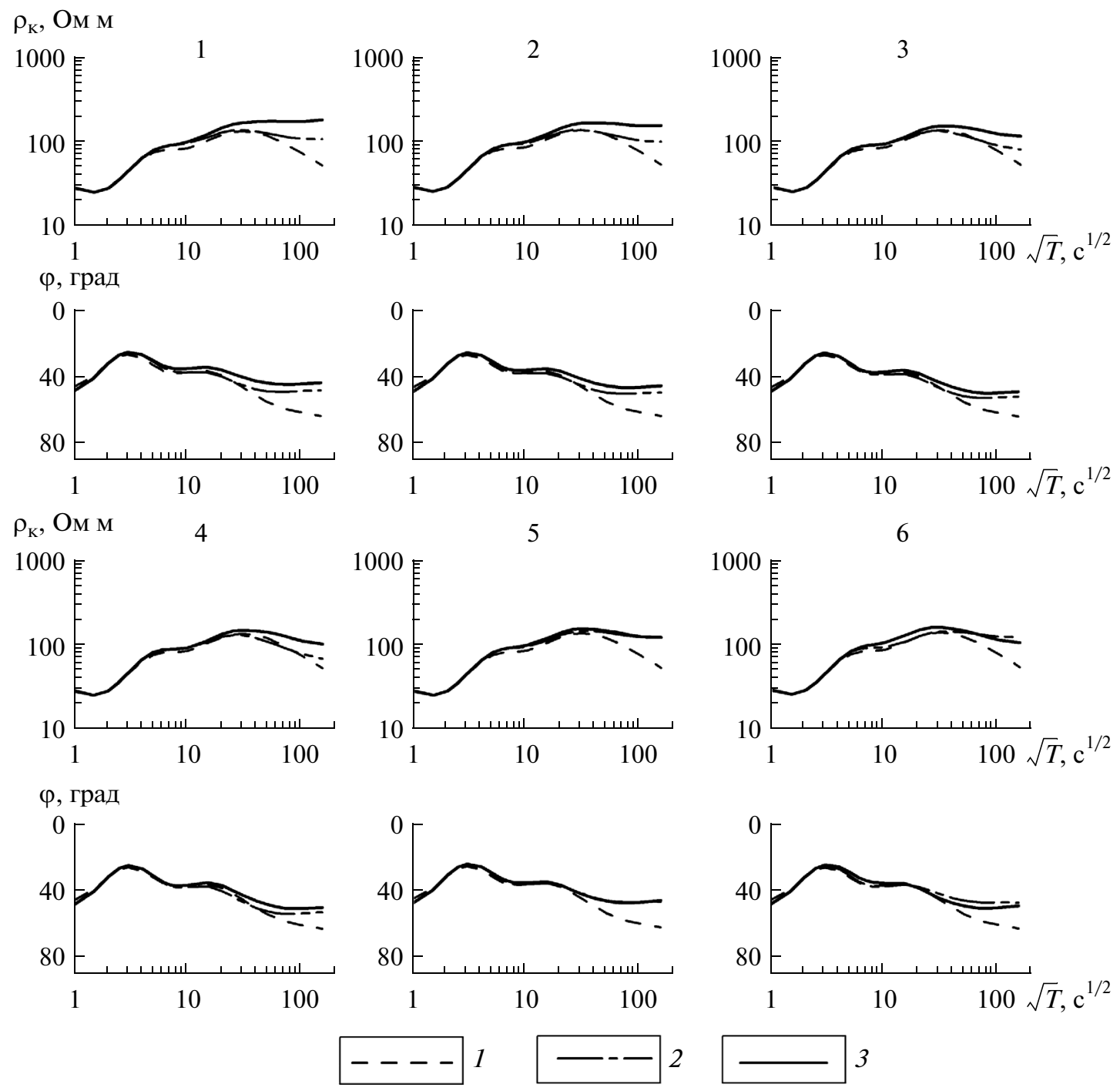

Рис. 6. Кривые МТЗ в пробной модели с литосферным проводящим слоем: 1, 2 и 3 - локально-нормальная, продольная и поперечная кривые МТЗ. Цифрами над кривыми обозначены номера пунктов, показанных на рис. 4.

кайнозойским осадочно-вулканогенным чехлом Вывенского прогиба, в котором значительная роль принадлежит терригенным толщам. В глубинных частях разреза проявились более значительные по величине проводящие зоны. В сильной мере выражены субвертикальные проводящие зоны в районах МТЗ № 211-204 и 184-176, которые могут быть обусловлены глубинными разломами. Они от приповерхностных частей земной коры проникают на глубины в десятки километров. Удельное электрическое сопротивление зон составляет первые десятки-единицы Ом м. Это на порядок-полтора порядка меньше удельного электрического сопротивления пород за пределами зоны. Судя по изолинии $\lg 1.4$ (25 Ом м), глубина проникновения проводящих зон около 45 км. Ширина зоны в районе МТЗ № 209 на глубинах 10-20 км составляет примерно 15 км, а в районе МТЗ 179-8 км. На этом уровне глубин электропроводность геологической среды является максимальной. На дневной поверхности проводящие зоны отвечают разломам, выявленным по данным геологической съемки. Разломы имеют СВ простирание, которое согласуется с простиранием основных тектонических элементов. Протяженность разломов составляет первые десятки километров.

На геоэлектрическом разрезе приведены графики гравитационного и магнитного полей (рис. 12). Аномалия отрицательных значений поля силы тяжести приурочена к юго-западной части профиля, где выявлены глубинные проводящие зоны. Они, по-видимому, отражают разуплотненный блок литосферы, выраженный отрицательной гравитационной аномалией. В этой части профиля магнитное поле характеризуется положительной аномалией, 

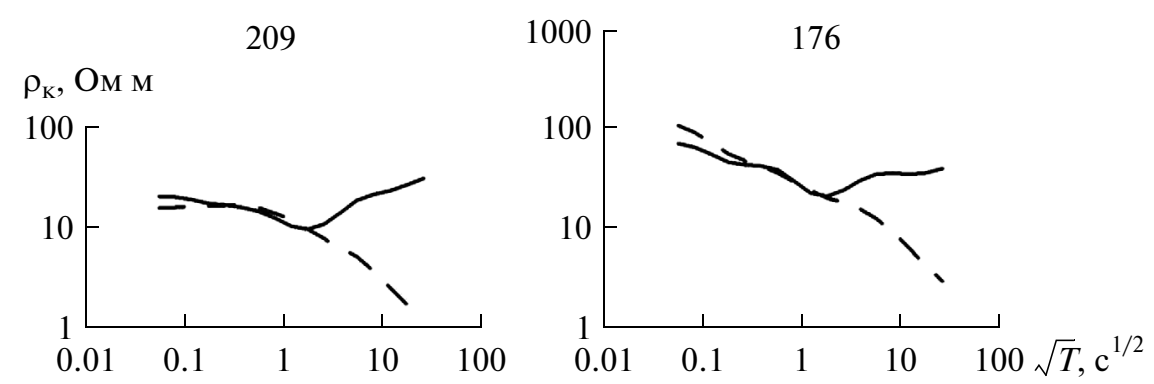

$\varphi$, град
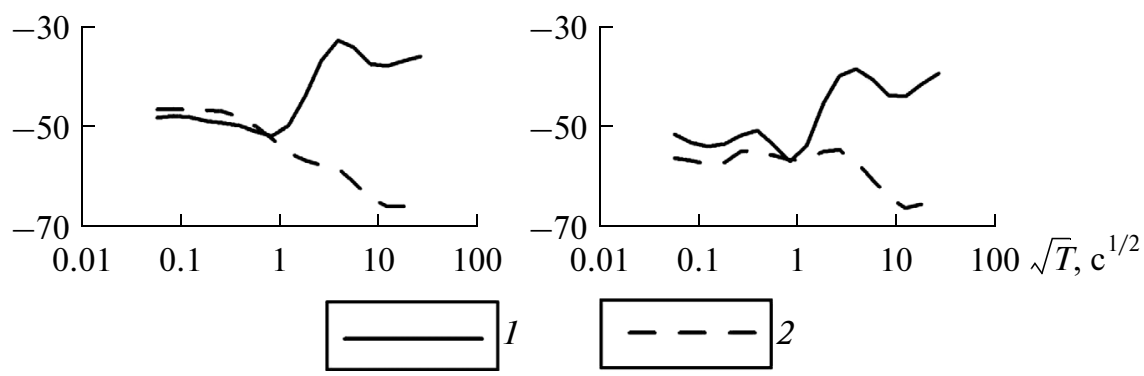

Рис. 7. Кривые МТЗ в районах глубинных разломов: 1 и 2 - поперечные и продольные МТЗ. Цифрами над кривыми обозначены номера пунктов МТЗ, приведенных на рис. 1. На верхней шкале цифрами обозначены номера пунктов МТ3 (см. рис. 1).

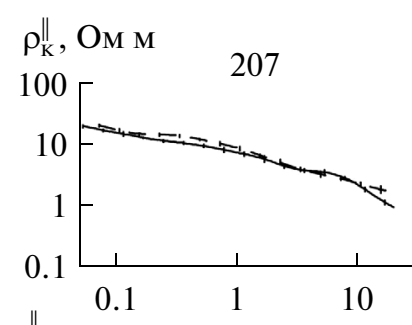

$\varphi^{\|}$, град
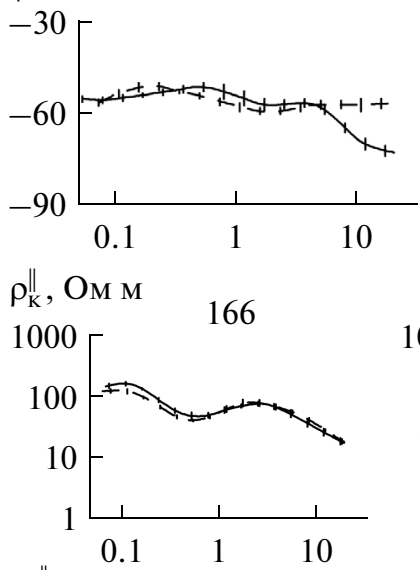

$\varphi^{\|}$, град

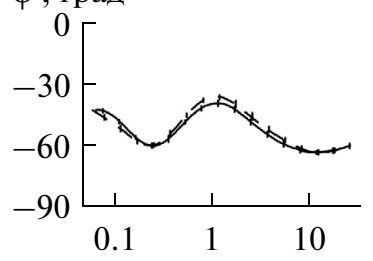

(a)

195
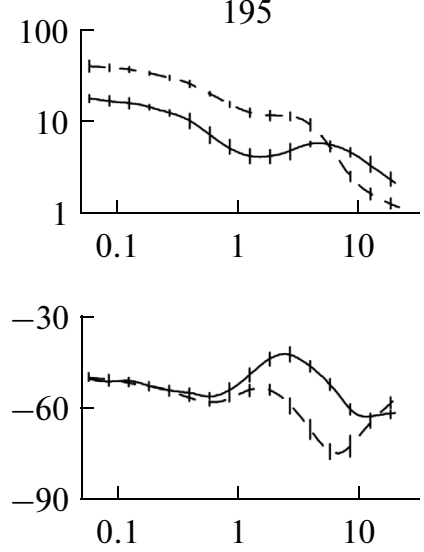

(б)
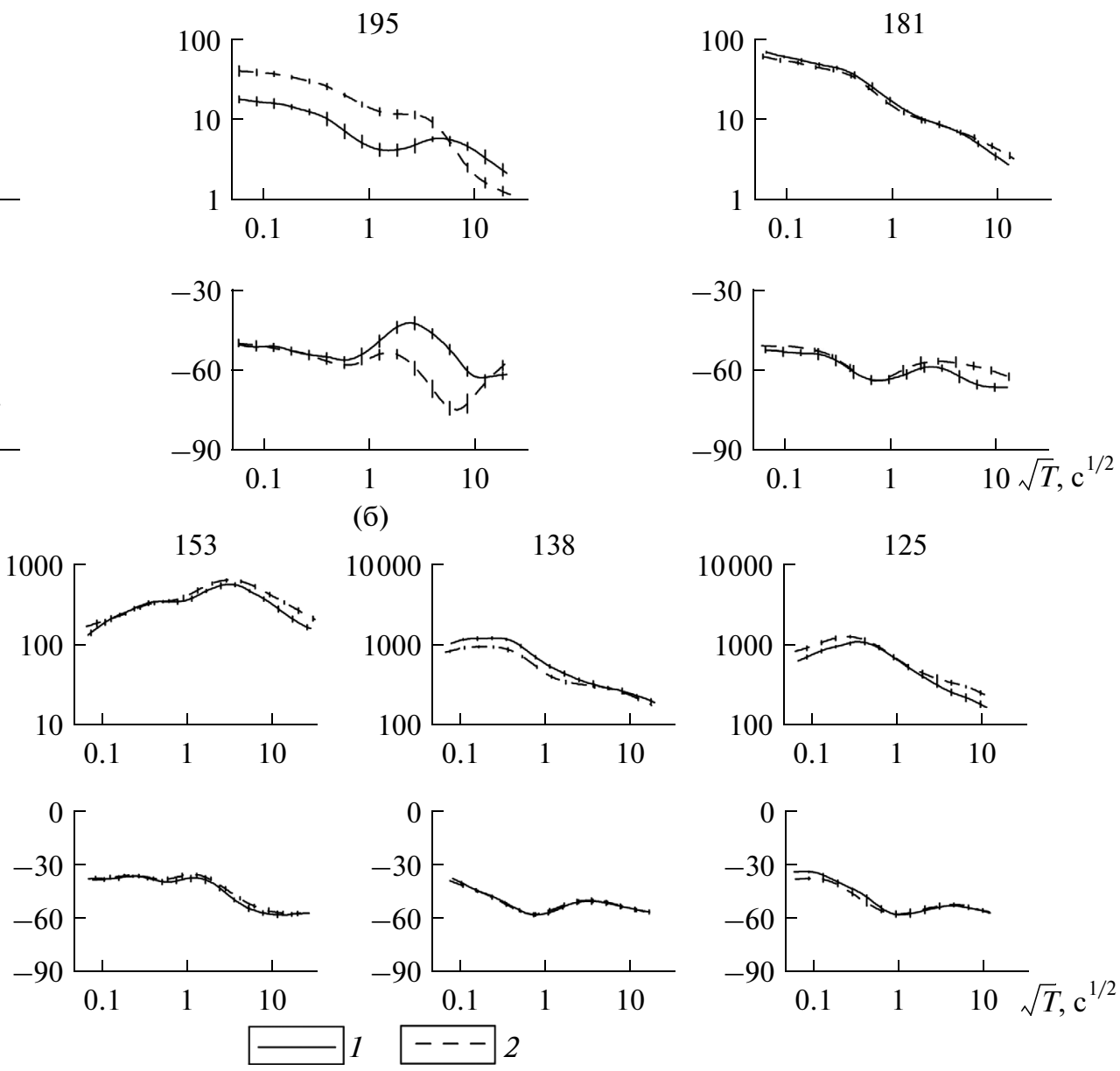

Рис. 8. Сопоставление продольных кривых МТЗ до и после землетрясения на профиле I-I: (а) и (б) - кривые МТЗ в районе глубинных разломов и за их пределами; 1 и 2 - кривые МТЗ до и после землетрясения. 


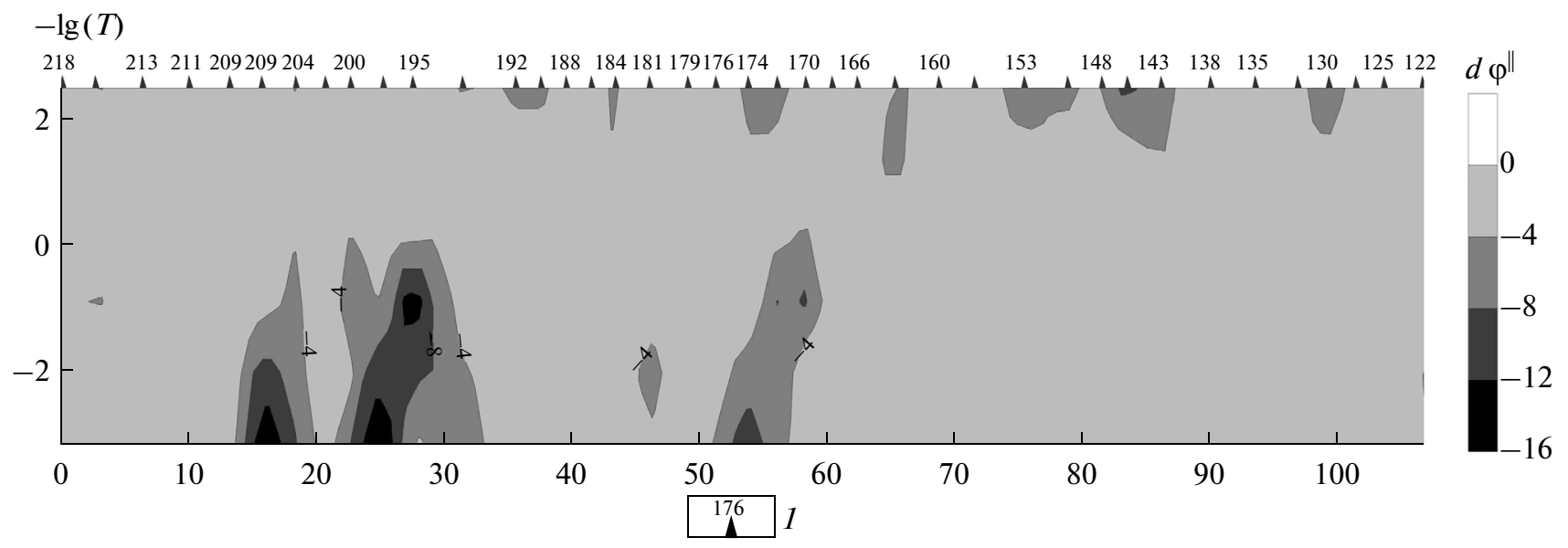

Рис. 9. Псевдоразрез разности фаз продольного импеданса до и после землетрясения по профилю I-I: 1 - пункт МТ3 и его номер (см. рис. 1).
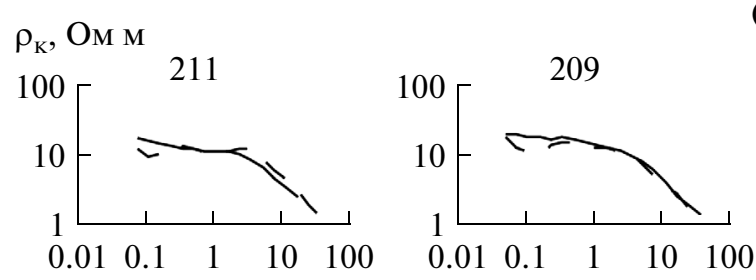

(a) $\varphi$, град
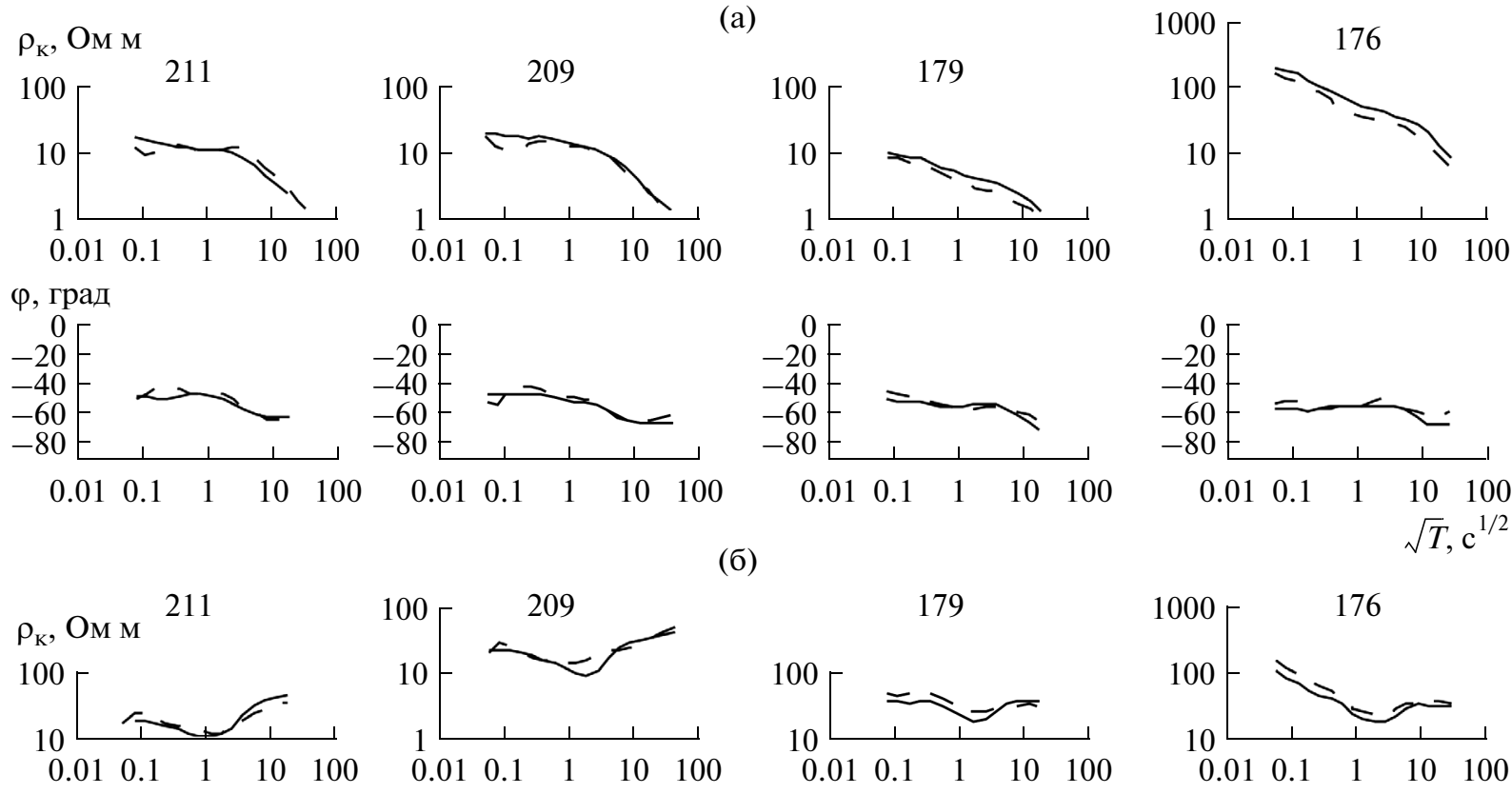

(б)
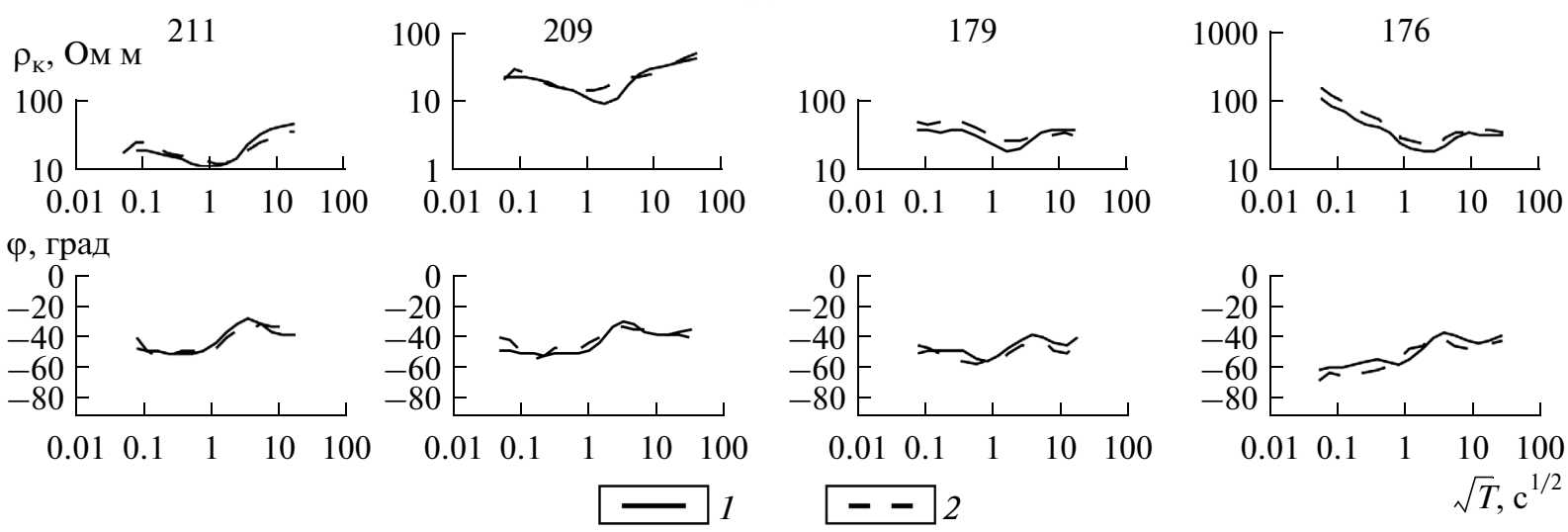

Рис. 10. Сопоставление экспериментальных и модельных кривых по данным МТЗ до землетрясения: (а) и (б) - поперечные и продольные кривые; 1 и 2 - экспериментальная и модельная кривые.

связываемой с наличием в осадочно-вулканогенном чехле магматических пород основного состава. Максимум гравитационного поля и минимум магнитного поля в районе МТ3 № 160 связаны с зоной глубинного разлома, разделяющего Корякскую и Олюторскую складчатые области. Зона отличает- ся насыщенностью разреза магматическими породами. Ее геоэлектрический разрез характеризуется повышенным электрическим сопротивлением.

После землетрясения структура электропроводности литосферы в значительной мере изменилась (рис. 13). В районе МТЗ № 211-204 шири- 

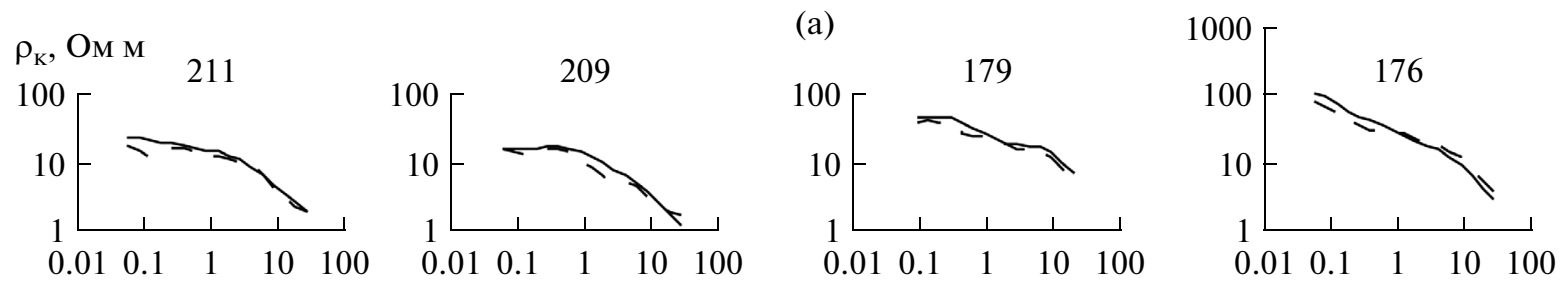

$\varphi$, град
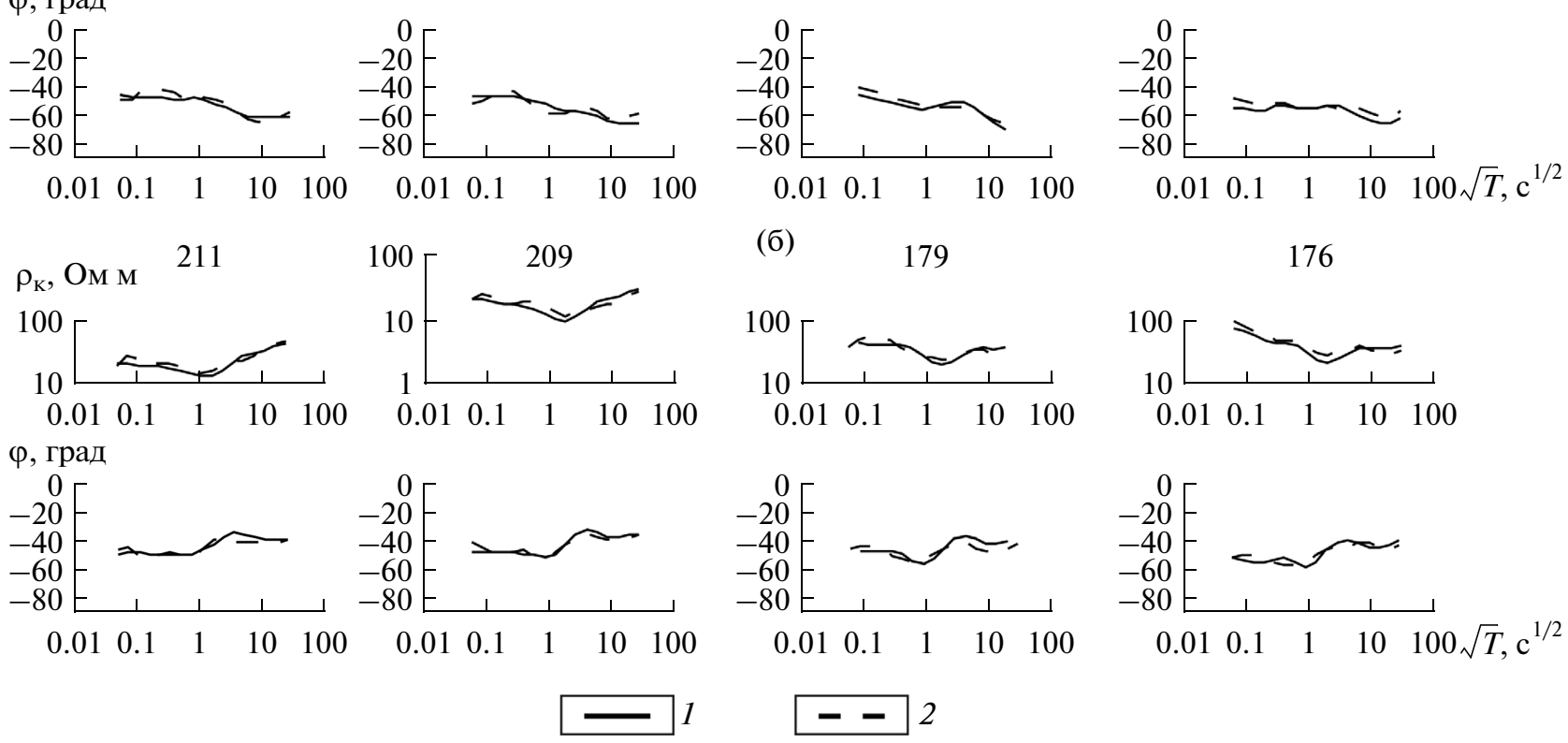

Рис. 11. Сопоставление экспериментальных и модельных кривых по данным МТЗ после землетрясения: (а) и (б) - поперечные и продольные кривые; 1 и 2 - экспериментальная и модельная кривые.

на проводящей зоны на глубинах 20-30 км уменьшилась почти в 2 раза. Глубина ее уменьшилась примерно в 1.5 раза. В районе МТ3 № 184-176 ширина проводящей зоны на глубинах 20-30 км увеличилась почти в два раза, а ее глубина увеличилась незначительно. Наряду с этим увеличилась электропроводность земной коры в районе МТЗ № 218. Гипоцентр Олюторского землетрясения по трем опредлениям $(\mathrm{a}, \mathrm{d}, \mathrm{c})$ из четырех приурочен к юго-западной границе проводящей зоны, выраженной высоким градиентом значений удельного электрического сопротивления. Характерно, что значительная часть гипоцентров афтершоков землетрясения приурочена к проводящей зоне в районе МТЗ № 211-204. Здесь, повидимому, земная кора была динамически неустойчивой. На дневной поверхности в районах проводящих зон (МТ3 № 209) и (МТ3 № 176) проявились сейсмотектонические разрывы СВ простирания протяженностью 80 и 140 км.

Рассмотрим геоэлектрический разрез по профилю II-II, выполненному после землетрясения (рис. 14). Он получен в результате инверсии кривых МТЗ и МВ3. В Вывенском прогибе (МТ3
№ 1-10) и в Пылговаямской впадине (МТ3 № 28-47) осадочно-вулканогенный чехол характеризуется повышенной электропроводностью с удельным электрическим сопротивлением в единицы-первые десятки Ом м, связанной с наличием в разрезе терригенных низкоомных толщ, которые могут иметь пониженную плотность. Это находит подтверждение в виде аномалий пониженной интенсивности гравитационного поля. В районе Хахинанского антиклинория (МТЗ № 20-28) верхняя часть земной коры характеризуется пониженной электропроводностью, что обусловлено насыщенностью разреза магматическими породами. Об этом свидетельствует повышенная напряженность гравитационного поля и возмущенное поведение магнитного поля. Локальные аномалии магнитного поля (МТ3 № 10 и МТ3 № 36) приурочены к градиентным зонам электропроводности земной коры, которые могут быть связаны с тектоническими нарушениями, контролирующими магматизм.

На рис. 14 хорошо видно, что в земной коре на глубинах 20-30 км (МТ3 № 1-38) выделяется слой повышенной электропроводности. Удельное 
$\Delta g, \mathrm{мГл}$

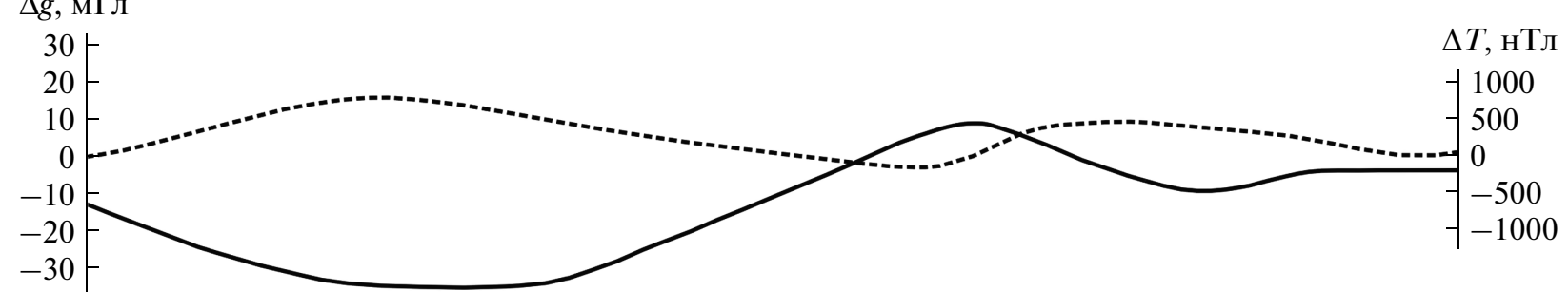

ОЛЮТОРСКАЯ СКЛАДЧАТАЯ ОБЛАСТЬ

КОРЯКСКАЯ

В

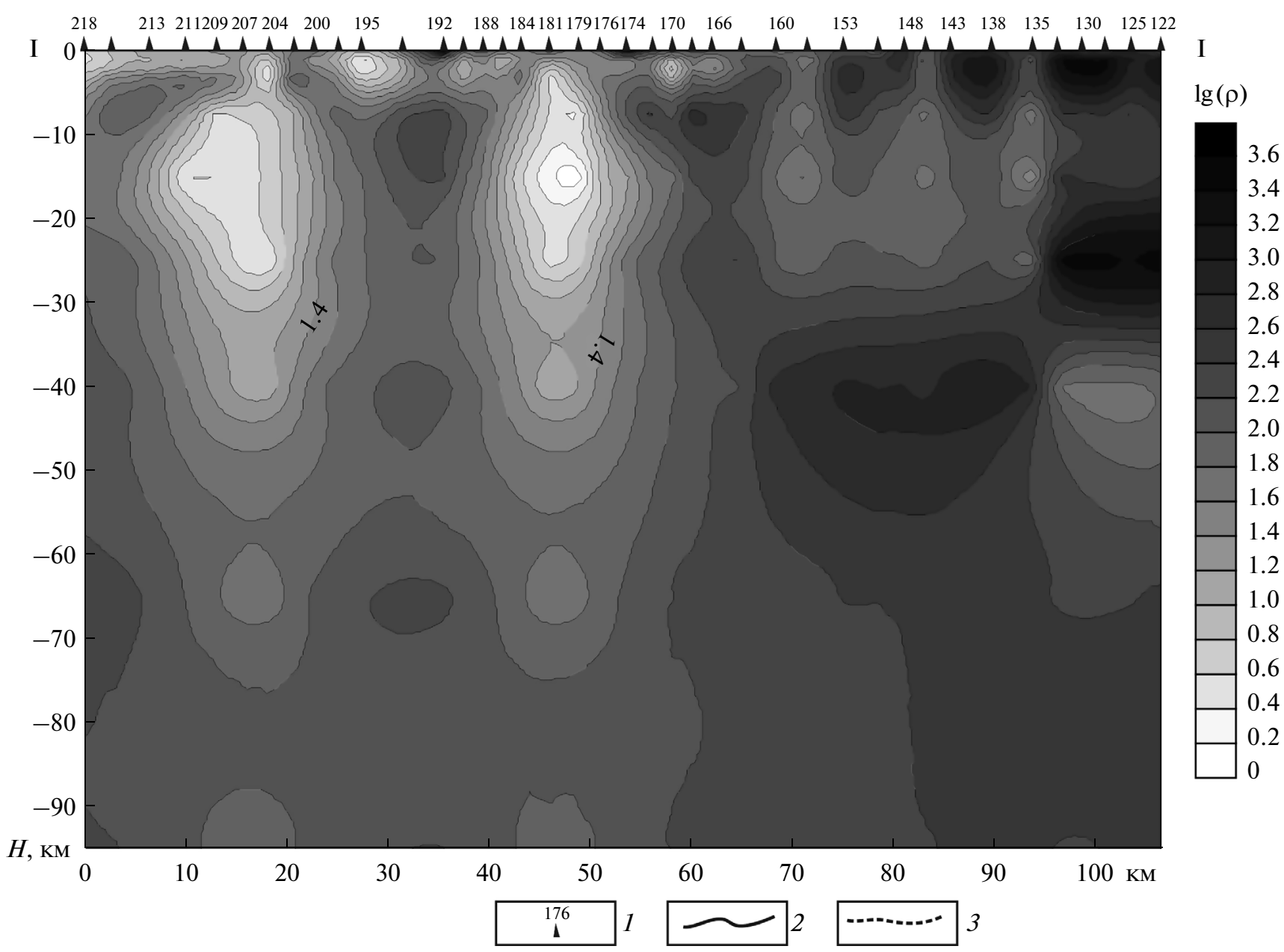

Рис. 12. Геоэлектрический разрез литосферы по данным МТЗ до землетрясения по профилю I-I: 1 - пункт МТ3 и его номер (см. рис. 1); 2 и 3 -графики поля силы тяжести и магнитного поля.

электрическое сопротивление слоя составляет единицы-первые десятки Ом м. Повышенная проводимость слоя отмечается в районе Хахинанского антиклинория (МТЗ № 18-28). В восточном направлении кровля слоя поднимается до глубины 10 км (МТ3 № 38-47). Поднятие проводящего слоя находит отражение в виде интенсивного минимума поля силы тяжести, свидетельствующего о возможном разуплотнении земной коры. В восточной части профиля в районе МТЗ № 1-7 в земной коре выделяется зона пониженного удельного электрического сопротивления. Она, по-видимому, является продолжением глубинной проводящей зоны выделенной на профиле I-I в районе МТЗ № 211-204. В районе профиля II-II проводимость зоны заметно уменьшается. Северо-восточное простирание зоны согласуется с направлением сеймотектонического разрыва на 


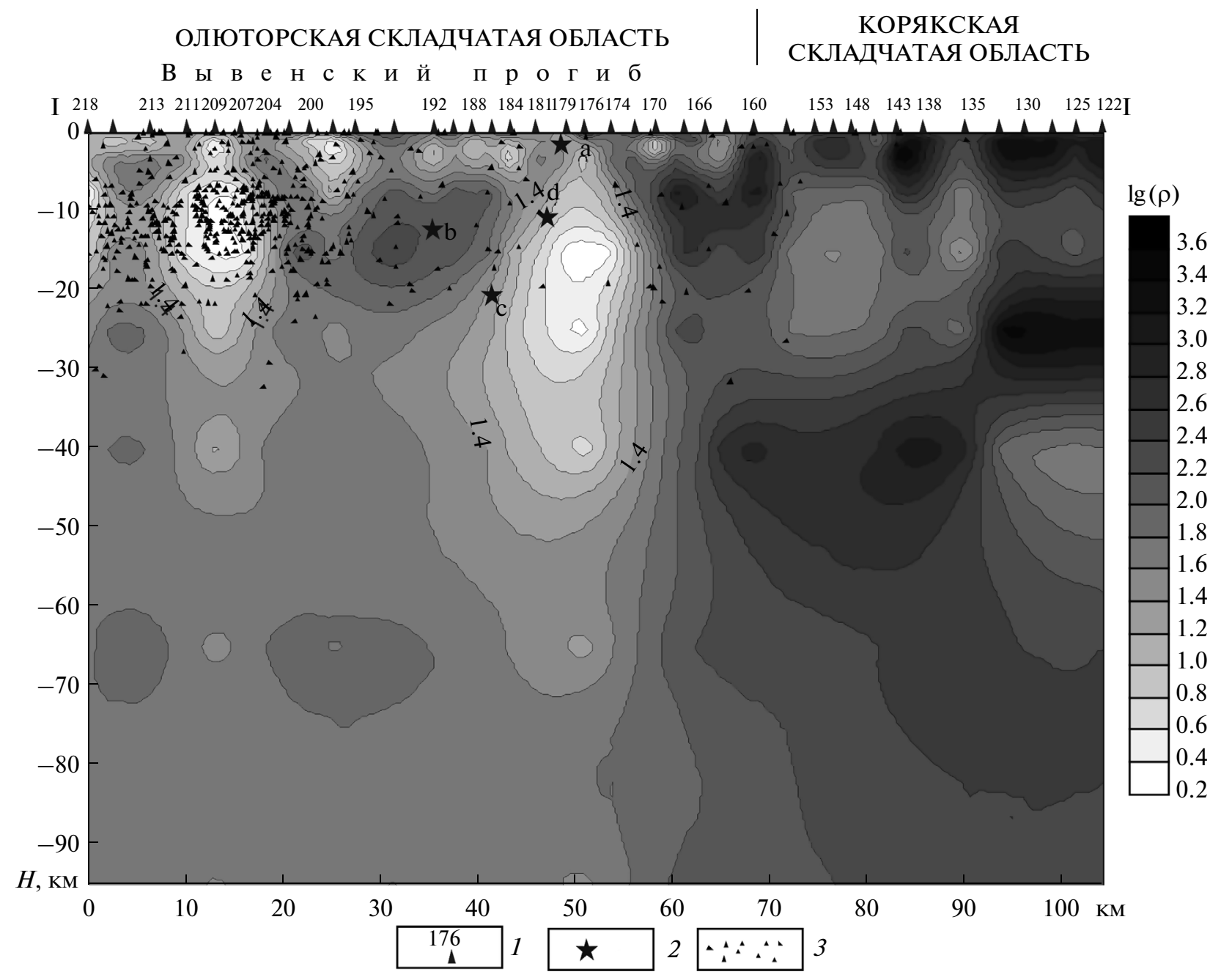

Рис. 13. Геоэлектрический разрез литосферы по данным МТЗ после землетрясения по профилю I-I: 1 - пункт МТЗ и его номер (см. рис. 1); 2 и 3 - гипоцентры Олюторского землетрясения и его афтершоков (см. рис. 1).

дневной поверхности, который также затухает в районе профиля II-II. На геоэлектрическом разрезе по профилю II-II приведены гипоцентр и афтершоки Олюторского землетрясения. Большинство афтершоков приурочено к верхней части земной коры с пониженным электрическим сопротивлением.

Предполагается, что проводящие зоны связаны с глубинными разломами. Повышенная электропроводность разломов обусловлена наличием высокоминерализованных растворов и магматических расплавов. Возникновение жидких флюидов возможно при снятии напряжений в литосфере при образовании разломов. Грубые оценки показывают, что достаточно сотых-десятых долей процента относительного объема флюида в связанных каналах, чтобы уменьшить сопротивление кристаллической горной породы от сотенпервых тысяч Ом м до первых десятков-единиц Ом м. Примерные расчеты показывают, что если принять удельное электрическое сопротивление флюида в земной коре равным 0.01 Ом м [Ваньян, Хайдман, 1996], то при удельном электрическом сопротивлении пород в первые единицы Ом м, пористость пород будет достигать первых единиц процентов только за счет сквозных каналов. Очевидно пористость будет больше, если учесть изолированные и тупиковые каналы. При удельном электрическом сопротивлении 100 Ом м пористость пород уменьшится на два порядка.

Таким образом, изменение электропроводности геоэлектрической среды в связи с Олюторским землетрясением может быть связано с изменением пористости пород и степени насышенности их минерализованными растворами. Это изменение вызвано геодинамическими процессами, которые, как видно из геоэлектрических разрезов, затронули толщу литосферы до глубины 70 км. 


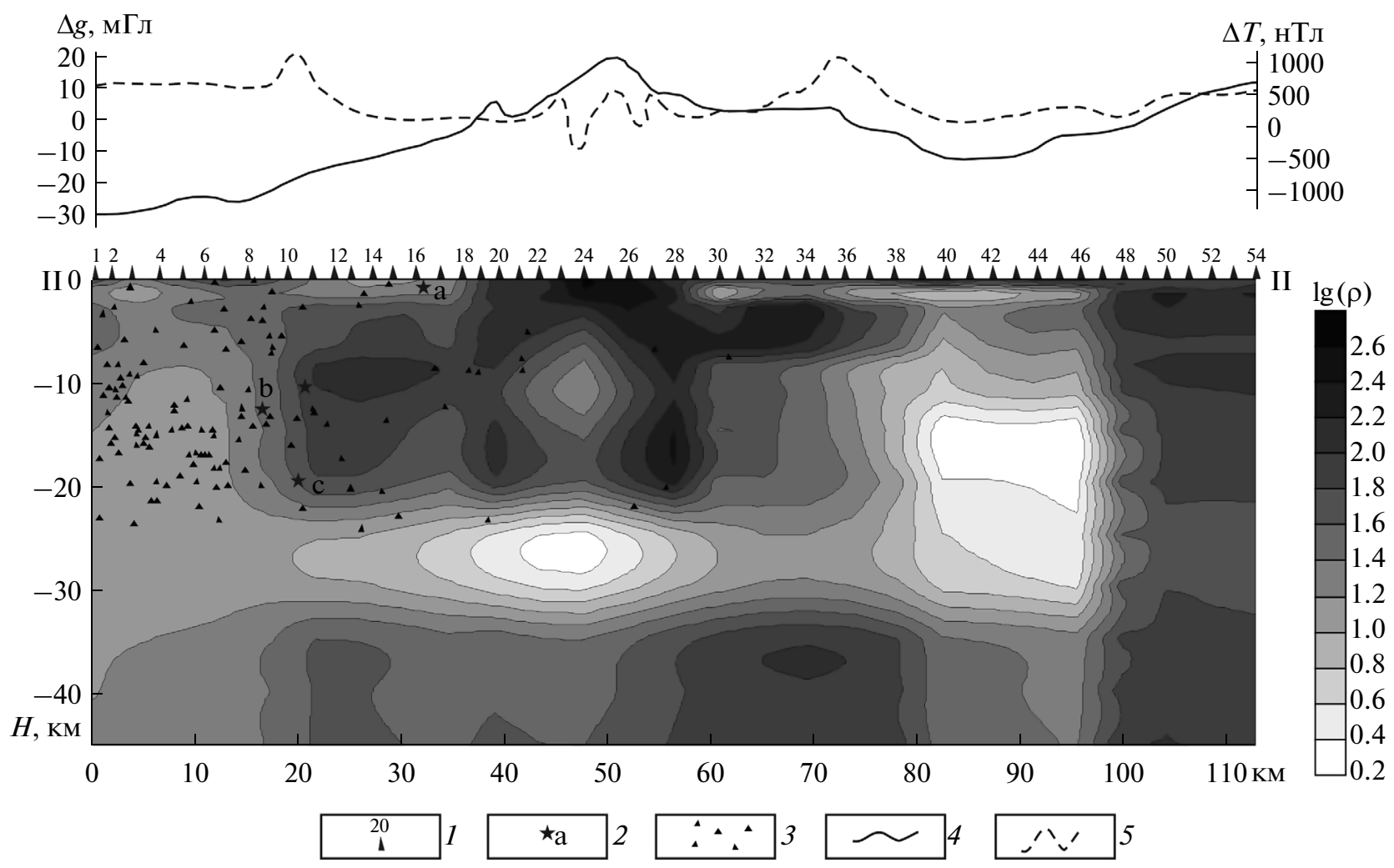

Рис. 14. Геоэлектрический разрез литосферы по данным МТЗ и МВЗ после землетрясения по профилю II-II: 1 - пункты МТЗ, МВ3 и их номер (нумерация пунктов указана через пикет); 2 и 3 - гипоцентры Олюторского землетрясения и его афтершоков (см. рис. 1); 4 и 5 - графики поля силы тяжести и магнитного поля.

\section{ВЫВОДЫ}

В основу интерпретации положены кривые МТЗ по направлениям, отвечающим простиранию и вкрест простирания основных тектонических элементов. Продольные и поперечные кривые МТ3 подвержены влиянию локальных геоэлектрических неоднородностей, что необходимо учитывать при изучении глубинного строения района. Результаты численного трехмерного моделирования показали, что данные кривые до периодов 400-900 с слабо затронуты влиянием берегового эффекта и характеризуют распределение глубинной электропроводности. Анализ экспериментальных и модельных данных свидетельствует, что продольные кривые в лучшей мере отражают наличие глубинного проводящего слоя, а поперечные кривые содержат информацию о разломах. На существование глубинных разломов указывает эффект расхождения ориентированных кривых МТЗ в низкочастотной области.

Обратная задача решена с помощью программы REBOCC, в которой использованы процедура сглаживания влияния локальных гальванических эффектов и совместная инверсия продольной и поперечной кривых МТЗ. В результате инверсии кривых зондирований получены геоэлектрические разрезы по профилю до и после землетрясения. Они свидетельствуют об изменении электропроводности литосферы Вывенского прогиба. После землетрясения уменьшилась аномалия повышенной электропроводности в литосфере, связываемая с глубинным разломом в районе МТЗ № 209, выраженным на дневной поверхности сейсмотектоническим разрывом протяженностью почти 80 км. При этом возросла по размерам и глубине аномальная зона высокой проводимости в литосфере в районе МТЗ № 176. Она связывается с глубинным разломом, находящим отражение на дневной поверхности в виде сейсмотектонического разрыва протяженностью около 140 км.

Зоны высокой проводимости в литосфере могут быть связаны с повышенной трещиноватостью пород и насыщенностью их минерализованными растворами. Большинство афтершоков Олюторского землетрясения приурочено к проводящей зоне в литосфере средней части Вывенской впадины. Предполагается, что в результате землетрясения уменьшилась трещиноватость и обводненность пород литосферы в этой части впадины в районе МТ3 № 209, но заметно возросла трещиноватость и обводненность пород в районе МТ3 № 176. 
Авторы признательны А.В. Ландеру за предварительное обсуждение статьи и критические замечания.

\section{СПИСОК ЛИТЕРАТУРЫ}

Апрелков C.E., Попруженко С.В. Пенжинско-ЗападноКамчатская складчатая зона и Укэлаят-Срединный блок в структуре Корякского нагорья и Камчатки // Тихоокеанская геология. 2009. Т. 28. № 4. С. 90-104.

Бердичевский М.Н., Дмитриев В.И. Модели и методы магнитотеллурики. Научный мир. 2009. С. 677.

Белявский В.В., Золотов Е.Е., Нурмухамедов А.Г., Ракитов В.А., Шиак И.П., Храпов А.В., Яковлев А.Г. Сейсмогеоэлектрическая модель Охотско-Чукотского вулканогенного пояса и Центрально-Корякской складчатой зоны по профилю Верхнее Пенжино-Корф // Геофизика. 2008. № 2. С. 30-44.

Ваньян Л.Л. Электромагнитные зондирования. М.: Научный мир. 1997. 219 с.

Ваньян Л.Л., Хайдман Р.Д. О природе электропроводности консолидированной коры // Физика Земли. 1996. № 4. С. 5-11.

Геология СССР. Северо-Восток СССР. Геологическое описание. Т. 30. Кн. І. М.: Недра. 1970а. 547 с.

Геология СССР. Северо-Восток СССР. Геологическое описание. Т. 30. Кн. II. М.: Недра. 1970б. 536 с.

Каталог землетрясений Камчатки и командорских островов 1962-2006. КФ ГС РАН. http://emsd.iks.ru

Ландер А.В., Левина В.И., Иванова Е.И. Сейсмическая история Корякского нагорья и афтершоковый процесс Олюторского землетрясения 20(21) апреля 2006 г. $M_{w}=7.6 / /$ Вулканология и сейсмология. 2010. № 2. C. $16-30$.

Ландер А.В., Букчин Б.Г., Дрознин Д.В. и др. Тектоническая позиция и очаговые параметры Хаилинского (Корякского) землетрясения 8 марта 1991 г.: существует ли плита Берингия? // Вычислительная сейсмология. Вып. 26. М. Наука. 1994. С. 103-122.

Мороз Ю.Ф. Глубинное строение юго-западной части Корякского нагорья // Советская геология. 1987. № 5. C. $118-123$.

Некрасов Г.Е. Тектоническая природа Корякско-Камчатского региона и вопросы геодинамики складчатого обрамления Тихого океана // Геотектоника. 2003. № 6. C. 53-79.

Пинегина T.K. Сейсмические деформации в эпицентральной зоне Олюторского землетрясения. Олюторское землетрясение (20(21) апреля 2006 г., Корякское нагорье). Первые результаты исследований. ПетропавловскКамчатский: КФ ГС РАН. 2007. С. 126-169.

Рогожин Е.А., Овсюченко А.Н., Мараханов А.В. и др. Олюторское землетрясение в Корякии 20(21) апреля 2006 г.: результаты геологического и макросейсмического изучения эпицентральной области. Олюторское землетрясение (20(21) апреля 2006 г., Корякское нагорье). Первые результаты исследований. Петропавловск-Камчатский: КФ ГС РАН. 2007. С. 170-206.

Смирнов Я.Б. Карта глубинных температур территории СССР и сопредельных районов в масштабе $1: 100000$. М.: ГУГЛ. 1980.150 с.

Сейсмологический бюллетень (ежедекадный) за 2006 год / Отв. ред. Старовойт О.Е. Обнинск: ГС РАН. ftp://ftp.gsras.ru/pub/Teleseismic_Catalog

Чехович В.Д., Сухов А.Н., Кононов М.В., Паланджсян С.А. Геодинамика северо-западного сектора тихоокеанского подвижного пояса в позднемеловое - раннепалеогеновое время // Геотектоника. 2009. № 4. С. 37-62.

Bahr K. Interpretation of magnetotelluric impedance tensor: regional, induction and local telluric distortion // J. Geophysics. 1988. № 62. P. 119-127.

Fujita K.K., Mackey K.G., Mc. Caleb R.C. et al. // Geol. Soc. Amer. Spec. Pap. 2002. V. 360. P. 259-272.

Harvard CMT catalog. http://www.globalcmt.org/ CMTsearch.html

Mackie K.L., Smith J.T., Madden T.R. Three-dimensional electromagnetic modeling using finite difference equations: the magnetotelluric example. Radio Science. 1994.

National Earthquake Information Centre, US Geological Survey, Earthquake date base http://neic.usgs.gov/neis/epic/ epic.html

Siripunvaraporn $W$., Egbert $G$. An efficient data-subspace inversion method for 2-D magneto telluric data // Geophysics. V. 65. № 3. 2000. P. 791-803.

Scholl D.W. Geological Society of America, abstracts with Programs. Berkeley (Calif.). 1999. V. 31. № 6. P. A92.

Swift C.M. A magnetotelluric investigation of an electrical conductivity anomaly in the Southwestern United States. Ph. D. Dissertation, M/T. Cambridge. 1967. 